\title{
¿Diente o pieza dentaria?
}

\author{
Pedro Aravena Torres ${ }^{1}$
}

1. CD, Doctor(c) en Ciencias Médicas. Profesor Instructor. Facultad de Medicina, Universidad Austral de Chile. Chile.

\section{Sr. Editor Revista Periodoncia, Implantología y Rehabilitación Oral:}

Al leer los artículos de la revista que usted dirige disponibles en formato electrónico, me doy cuenta de la discrepancia que existen entre los autores para definir algo fundamental en nuestra profesión: "Diente o Pieza Dentaria". Al hacer un breve ejercicio bibliográfico, un $47 \%$ de los artículos que usaron como modelo de observación al diente lo nombraron como "pieza dentaria".

Es interesante discutir acerca de este concepto a fondo ya que en referirse a los dientes como "piezas" no solo es un error sino que conlleva a una visión sesgada de la Odontología. Por ejemplo, dudo que los oftalmólogos se refieran al ojo como pieza ocular, sin embargo, los dentistas usualmente hablan de piezas dentarias en lugar de dientes ${ }^{(1)}$. Por eso, lo invito a analizar este término a fondo.

La palabra "diente" proviene del latin dens, dentis y "odontología" del griego antiguo odon. Se define como un órgano de consistencia muy dura y de color blanco, implantados en alveólos dentales del maxilar y la mandíbula ${ }^{(2)}$, órgano porque está formado por tejidos que se originan de distintas capas embrionarias, siendo una de las estructuras más completas y complejas de nuestro organismo. La Real Academia de la Lengua Española la define como un cuerpo duro que, engastado en las mandíbulas del hombre y de muchos animales, queda descubierto en parte, para servir como órgano de masticación o de defensa.

La última edición internacional de Nomenclatura Anatómica llustrada ${ }^{(3)}$ describe a este órgano como DENTES o dientes y con ello lo clasifica según su cronología en dientes desiduos (antiguamente llamados dientes caducos, temporales o dientes de leche) y dientes permanentes; y según su forma y función en dientes incisivos, caninos, premolares y molares.

Ahora, ¿qué dicen los encargados de dar nombre a las estructuras anatómicas de nuestro cuerpo?, los Morfólogos cada año se reúnen en los llamados Simposios Iberoamericanos de Terminología (SILAT) donde discuten la nomenclatura anatómica correcta acorde al origen etimológico de las palabras basándose en el libro "Handbook of Avian Anatomy: Nomina Anatomica Avium". Pues en él describen como "diente" a este órgano, y en ningún caso con otro apelativo o nombre.

Como hemos visto la evidencia bibliográfica no señala en ninguna parte al "diente" como "pieza dentaria". A ello sumémosle el alfabeto inglés quien lo nombra como "tooth" en singular y "teeth" en plural. Dicha lengua nos permite entender en artículos y revistas científicas internacionales al órgano en particular y no a una pieza como tal. En una búsqueda bibliográfica nunca encontraremos algún resultado con "tooth piece".

Con esto, se deja en evidencia que debemos usar correctamente el nombre "diente", tanto en la clínica, investigación y docencia. Por ello, lo invito a que pueda exigir el correcto uso de este órgano que, por su complejidad morfológica y funcional, merece todo el respeto de llamarlo como debe ser.

\section{REFERENCIAS BIBLIOGRÁFICAS}

1. Uribe S. ¿Diente o pieza dental? Disponible en: http://my.opera.com/ suribe/blog/

2. Rouvière $H$, Delmas $A$. Anatomía humana descriptiva, topográfica y funcional. Tomo 1. 10ª edición. Editorial Masson, 1999. Pág. 390.
3. Dauber, W. Feneis. Nomenclatura anatómica ilustrada. $5^{\text {ta }}$ edición. Editorial Masson, 2001. Pág. 136. 